\title{
Herpetofauna of the Quaternary sand dunes of the Middle Rio São Francisco, Bahia, Brazil. VIII. Amphisbaena arda sp. nov., a fuliginosa-like checkered patterned Amphisbaena (Squamata, Amphisbaenidae)
}

Miguel Trefaut Rodrigues

Departamento de Zoologia, Instituto de Biociências, Universidade de São Paulo, Caixa Postal 11.461, CEP 05422-970, São Paulo, SP, Brazil. E-mail: mturodri@usp.br.

\begin{abstract}
Herpetofauna of the Quaternary sand dunes of the Middle Rio São Francisco, Bahia, Brazil. VIII. Amphisbaena arda sp. nov., a fuliginosa-like checkered patterned Amphisbaena (Squamata, Amphisbaenidae). Amphisbaena arda sp. nov. is described based on a specimen obtained at Mocambo do Vento, on the left bank of the São Francisco river, Bahia State, Brazil. A. arda is a medium sized amphisbaenian with a checkered black and white color pattern similar to the one present in the fuliginosa group but differing from that by having a lighter pigmentation, an uniformly white ventral surface, and by several other important morphological characters. A. arda is similar to Amphisbaena vermicularis in meristic characters currently used to assist amphisbaenian identification but can be separated from it by its color pattern, its flatter cephalic shields, and by the more ventral position of nostril.
\end{abstract}

Keywords: Amphisbaena arda, Amphisbaenidae, Squamata, Caatingas, Brazil.

\section{Introduction}

The squamate fauna of the fossil dunes of the middle Rio São Francisco in the Brazilian semiarid Caatingas, State of Bahia, is characterized by high richness and endemism. An important part of squamates from the area was described in the last few years, including new genera, some showing unsuspected morphological adaptations for life on sand in

Received 19 November 2002

Accepted 29 December 2002
South America. Four new genera and a total of 21 new species of squamates, most endemic, were described from the region (Rodrigues 1984a, b, c, 1986, 1991a, b, c, d, 1993a, b, 1996, Rodrigues and Juncá 2002, Rodrigues et al. 1988, Vanzolini 1991a, b). It has been suggested that some of the endemic squamates form allopatric pairs of sister species occupying adjacent and opposite sand habitats along the river (Rodrigues 1996, Rodrigues and Juncá 2002). Although additional surveys in the area are still revealing the existence of undescribed lizards, snakes, amphisbaenians, and frogs, and 
confirming the uniqueness of this region, most of the invertebrate fauna remains largely unexplored (see Rodrigues 1996 and Rodrigues and Juncá 2002, respectively, for a detailed description of the area and a list of references on the fauna).

Six species of amphisbaenians are known to occur in the dunes of middle Rio São Francisco; three of them are endemics: Amphisbaena frontalis, A. hastata, and A. ignatiana (Rodrigues 1996, Vanzolini 1991a, b). The other three species are $A$. pretrei, A. vermicularis, and Leposternon polystegum.

In a recent trip to the region, an unusual medium-sized Amphisbaena with a characteristic checkered black and white pattern, reminding that present in the fuliginosa group of Amphisbaena, was obtained in the dunes of the left bank of the Rio São Francisco. However, after a more careful examination, this unique specimen revealed to be unrelated to the fuliginosa group. Although keyed out and apparently close to $A$. vermicularis the specimen is so distinct from that species and all other congeners that it is herein described as a new species.

\section{Species Description}

Amphisbaena arda sp. nov.

(Figures 1 and 2)

Holotype - MZUSP 91638, Mocambo do Vento (1049'13"S, 42 52'26”W), Ibiraba: State of Bahia: Brazil, collected by M. T. Rodrigues, F. Curcio, F. F. Oliveira, J. C. Passoni, and M. Dixo on 16 May 2000; field number MRT 3642.

Etymology - from the Greek "arda", dirty; a reference to the unclean color pattern of the new species, predominantly milky-white with irregular and scattered black spots.

Diagnosis - A medium-sized Amphisbaena with an elongate snout, paired nasals, frontals and parietals, 242 body and 30 caudal annuli, 23 dorsal and 23 ventral segments per annuli at midbody, 4 precloacal pores, 4 supralabials, and 3 infralabials. The distance between nostril and upper lip equals distance from nostril to suture between nasals. Additionally the new species differs from all other Amphisbaena by presenting a checkered black and white pattern which is restricted to dorsal and lateral parts of body; the ventral surface is immaculate creamy white.

Description of the holotype - (Figures 1 and 2). A medium-sized amphisbaenid with an elongate snout, a total length of $330 \mathrm{~mm}(285$ + 45) and $9 \mathrm{~mm}$ diameter at midbody. Head not distinct from neck, mouth ventral. Rostral scarcely visible from above, subtriangular, contacting first supralabial, and nasal, their larger contact with the latter. Nasals, frontals and parietals in broad contact at midline. Nasal large, quadrangular, in broad contact with first supralabial and frontal. Nostril lateral, in the anteroventral part of nasal. Frontal larger than nasal, longer than wide, shorter at midline suture, longer at labial border; suture between frontals about the same size of suture between nasals and parietal suture. Parietals subtriangular, longer than wide, following frontals and in slight contact with ocular. A pair of enlarged occipitals in contact at midline followed posteriorly by smaller scales towards the first body annulus. Four supralabials in the following order of decreasing size of their base: first, second, third and fourth. The first three diagonally oriented. First supralabial below nasal, in slight contact with frontal. Second and third supralabials higher than long, second one contacting prefrontal and ocular, third one contacting the ocular and temporal. Ocular quadrangular, with the eye in the dorsoposterior part of scale. Between occipital and the fourth supralabial level, two longitudinal rows of temporals decreasing gradually in size ventrally; anterior scale of the dorsal row larger, contacting ocular. 

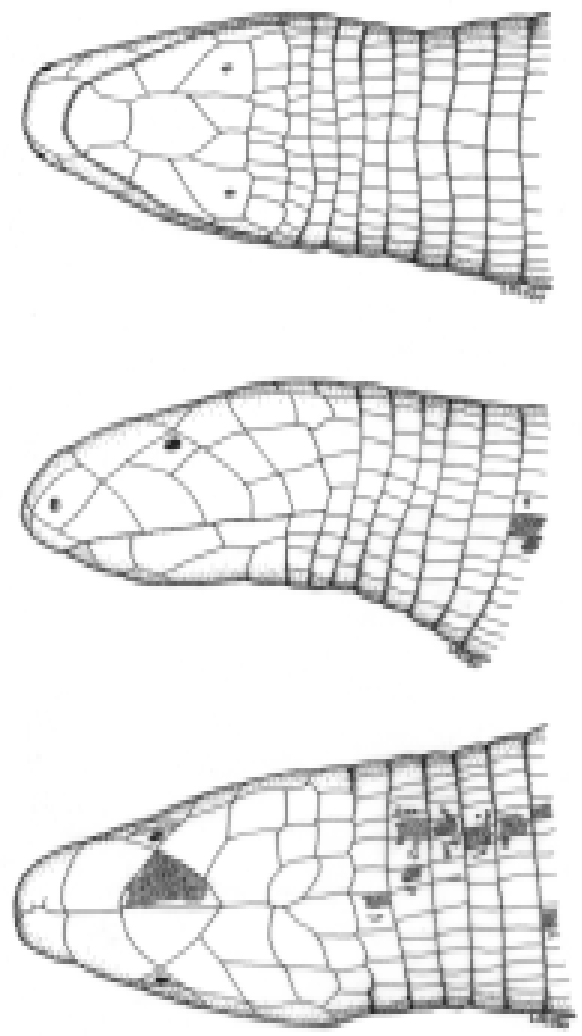

Figure 1 - Amphisbaena arda: ventral, lateral, and dorsal views of head (MZUSP 91638, holotype). Bar $=1 \mathrm{~mm}$.

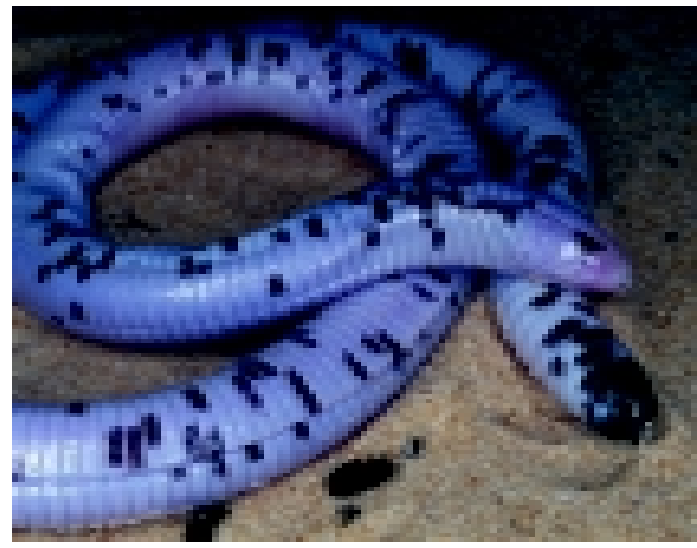

Figure 2 - Amphisbaena arda: color in life of the holotype (MZUSP 91638) from Mocambo do Vento, State of Bahia, Brazil.
Mental smaller than rostral, as long as wide, wider anteriorly, their lateral margins concave and converging posteriorly to a large and truncate posterior margin. Postmental single, longer than wide, about twice as long as mental; its posterior part triangular indenting deeply two symmetric and slightly enlarged chin shields (postgenials) in contact at midline. Between the latter and infralabials a much larger malar which additionally contacts second and third infralabials, and postmental. Malar contacting posteriorly a slightly enlarged scale, the only differentiated in the annulus and in contact with third infralabial. Three infralabials, second the largest; first as long as wide, third longer than wide.

Body annuli well marked with regular and conspicuous segments separated by lateral grooves. Segments of first three annuli as long as wide, from there on becoming gradually longer than wide; 242 body and 30 caudal annuli; 23 dorsal and 23 ventral segments per

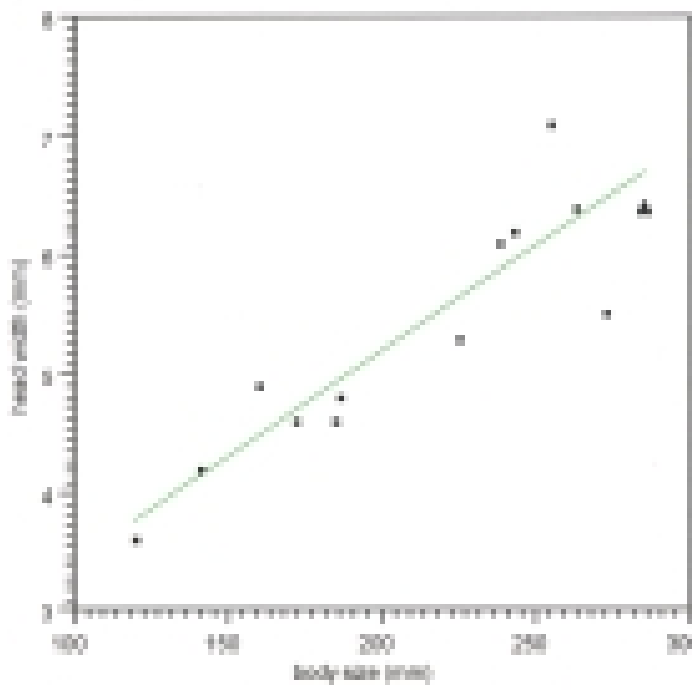

Figure 3 - Regression of head width on body length for the specimens of Amphisbaena vermicularis from Santo Inácio and Vacaria, State of Bahia, Brazil $\left(r^{2}=0.78\right)$. For comparison, the holotype of $A$. arda (triangle) is indicated. 
annuli at midbody. First complete annulus separated from the parietal by three scales. Ventral segments larger towards the midventral area, the two midventral segments of each annulus distinctively enlarged between the seventh body segment and precloacal region.

Four distinctive precloacal pores. Anal flap semicircular, with eight enlarged scutes, the central ones the largest, longer than wide. Tail with regular segmentation, characteristically with segments longer than those of body after the autotomic annulus. Autotomic site marked at eighth annulus and defined either by its longer segments and the beginning of the wider part of tail. Tip of tail smooth, rounded.

Dorsal ground color creamy white with scattered and irregularly shaped black spots. Head creamy white except for the right parietal which is black. Venter creamy white, immaculate. Tip of tail entirely black.

Natural History - The specimen of Amphisbaena arda was collected at Mocambo do Vento, along with 25 specimens of A. hastata and 5 specimens of Leposternon polystegum. Except for the holotype of $A$. arda, most of the other specimens are damaged because they were obtained following a tractor preparing the area for setting up a road connecting Ibiraba to Barra across the dunes. All specimens are in MZUSP collection and were found directly in the sand. A detailed description of the general area can be found in Rodrigues (1991a, 1996). Collection effort following the tractor during two consecutive days was equivalent to 40 hours/men and suggests that Amphisbaena arda is rare in this area.

\section{Discussion}

Comparisons below are based on Vanzolini (1991b, 2002), supplemented by data from a series of specimens of Amphisbaena vermicularis recently obtained from Santo Inácio, Bahia (MZUSP 91639 - 91643).

Although Amphisbaena arda resembles $A$. fuliginosa in having a checkered black and white pattern, these two amphisbaenians are very distinct. There is no overlapping in counts of body annuli (190-220; 242), as well as in number of dorsal and ventral segments at midbody (10-13/9-13, 23/23), number of pores (6-10;4), and body color. A. arda has an immaculate venter whereas in A. fuliginosa the ventral color varies from a checkered pattern identical to dorsal color to a slightly black mottled ventral surface but never immaculate. $A$. arda keys out perfectly as A. vermicularis, traditional counts currently used to assist amphisbaenian identification being inappropriate to distinguish these two species (Vanzolini, 2002): number of body annuli (211254; 242 in $A$. arda); tail annuli (23-30; 30); dorsal and ventral segments at midbody (18-26/ $18-25 ; 23 / 250)$; number of pores (4); and presence or absence of major cephalic shields. The picture is the same if we restrict our comparisons to specimens of A. vermicularis from Santo Inácio and Vacaria, two geographically closer localities in the State of Bahia, both on the right bank of the Rio São Francisco in the dune area: body annuli (230-244; 242), tail annuli (28-29; 30), and dorsal and ventral segments at midbody, respectively (18-23/19-23; 23/25).

Despite this apparent similarity, the two species are very different. The head scales of $A$. arda are flat, never swollen whereas in $A$. vermicularis the head scales are characteristically swollen. A. vermicularis has a typical occipital depression middorsally marked by a definite sulcus extending from the posterior border of parietals to the 3 rd-5th annulus posterior to the angulus oris, segmental scales in the occipital depression being inclined toward midline. On the other hand, there is no such occipital depression in A. arda. Another important distinctive difference is the position of the nostril, which is more ventrally placed in $A$. arda. In the latter, straight distance between nostril and upper lip equals straight distance from nostril 
to suture between nasals whereas in $A$. vermicularis the distance from the nostril to the midnasal suture is much larger than the distance from the nostril to the adjacent upper lip. This character seems to be taxonomically significant because, considered together with differences described in the degree of swollening of head scales and in occipital region, is probably indicative of additional osteological and/or myological differences.

The first temporal is much larger than the ocular in Amphisbaena arda (same size in A. vermicularis). In $A$. vermicularis the occular contacts posteriorly the two temporals whereas in $A$. arda there is only one temporal contacting the ocular. In $A$. arda the suture between nasal and frontal is coincident with the posterior part of the first supralabial. The same suture reaches the second supralabial in A. vermicularis.

To date, A. vermicularis was never found in the main dune field of the left bank of the Rio São Francisco. Nevertheless, several specimens were obtained in nearby areas, at Santo Inácio and Vacaria, both localities being within the core region of the dunes but on opposite sides of the river. The regression of head width on body size for specimens of A. vermicularis (and data obtained for the holotype of $A$. arda) indicates that they are also very similar in body proportions (Figure 3 ).

\section{Acknowledgements}

I thank Fundação de Amparo à Pesquisa do Estado de São Paulo (FAPESP) and Conselho Nacional de Desenvolvimento Científico e Tecnológico (CNPq) for support. For their invaluable help in the field, I thank Felipe Curcio, Marianna Dixo, Francisco Filho de Oliveira, J. C. Passoni, and the people of Icatú (Ibiraba officially). I also thank Nelson Jorge da Silva Jr., who kindly offered us a four wheel drive vehicle for the trip, Luciana Lobo for the drawing, and Hussam Zaher and Carolina Castro-Mello for access to specimens.

\section{References}

Rodrigues, M. T. 1984a. Nothobachia ablephara: novo gênero e espécie do nordeste do Brasil (Sauria: Teiidae). Papéis Avulsos de Zoologia, São Paulo 35: 361-366.

Rodrigues, M. T. 1984b. Uma nova espécie brasileira de Tropidurus com crista dorsal (Sauria, Iguanidae). Papéis Avulsos de Zoologia, São Paulo 35: 169-175.

Rodrigues, M. T. 1984c. Sobre Platynotus Wagler, 1890, pré-ocupado, substituído por Tapinurus Amaral, 1933, com a descrição de uma nova espécie (Sauria, Iguanidae). Papéis Avulsos de Zoologia, São Paulo 35: $367-373$.

Rodrigues, M. T. 1986. Um novo Tropidurus com crista dorsal do Brasil com comentários sobre suas relações, distribuição e origem (Sauria; Iguanidae). Papéis Avulsos de Zoologia, São Paulo 36: 171-179.

Rodrigues, M. T. 1991a. Herpetofauna das dunas interiores do rio São Francisco, Bahia, Brasil. I. Introdução à área e descrição de um novo gênero de microteiídeos (Calyptommatus) com notas sobre sua ecologia, distribuição e especiação (Sauria, Teiidae). Papéis Avulsos de Zoologia, São Paulo 37: 285-320.

Rodrigues, M. T. 1991b. Herpetofauna das dunas interiores do rio São Francisco, Bahia, Brasil. II. Psilophthalmus: um novo gênero de Microteiidae sem pálpebra (Sauria, Teiidae). Papéis Avulsos de Zoologia, São Paulo 37: 321-327.

Rodrigues, M. T. 1991c. Herpetofauna das dunas interiores do rio São Francisco, Bahia, Brasil. III. Procellosaurinus: um novo gênero de microteiídeos sem pálpebra, com a redefinição do gênero Gymnophthalmus (Sauria, Teiidae). Papéis Avulsos de Zoologia, São Paulo 37: 329-342.

Rodrigues, M. T. 1991d. Herpetofauna das dunas interiores do rio São Francisco, Bahia, Brasil. IV. Uma nova espécie de Typhlops (Ophidia, Typhlopidae). Papéis Avulsos de Zoologia, São Paulo 37: 343-346.

Rodrigues, M. T. 1993a. Herpetofauna das dunas interiores do rio São Francisco: Bahia: Brasil. V. Duas novas espécies de Apostolepis (Serpentes, Colubridae). Memórias do Instituto Butantan 54: 53-59 (1992).

Rodrigues, M. T. 1993b. Herpetofauna of palaeoquaternary sand dunes of the middle São Francisco river: Bahia: Brazil. VI. Two new species of Phimophis (Serpentes: Colubridae) with notes on the origin of psammophilic adaptations. Papéis Avulsos de Zoologia, São Paulo 38: $187-198$.

Rodrigues, M. T. 1996. Lizards, snakes, and amphisbaenians from the Quaternary sand dunes of the middle Rio São Francisco, Bahia, Brazil. Journal of Herpetology 30: 513-523.

Rodrigues, M. T. 2003. Herpetofauna da Caatinga. In M. 
Tabarelli, J. M. C. Silva and I. Leal (eds.), Biogeografia, Ecologia e Conservação da Caatinga. Recife. Editora da Universidade Federal de Pernambuco (in press).

Rodrigues, M. T., S. Kasahara, and Y. Yonenaga-Yassuda. 1988. Tropidurus psammonastes: uma nova espécie do grupo torquatus com notas sobre seu cariótipo e distribuição (Sauria, Iguanidae). Papéis Avulsos de Zoologia, São Paulo 36: 307-313.

Rodrigues, M. T. and F. A. Juncá. 2002. Herpetofauna of Quaternary sand dunes of the middle São Francisco river: Bahia: Brazil. VII. Typhlops amoipira sp. nov., a possible relative of Typhlops yonenagae (Serpentes, Typhlopidae). Papéis Avulsos de Zoologia, São Paulo 42: 323-331.
Vanzolini, P. E. 1991a. Two new small species of Amphisbaena from fossil dune field of the middle Rio São Francisco, State of Bahia, Brasil (Reptilia, Amphisbaenia). Papéis Avulsos de Zoologia, São Paulo 37: 259-276.

Vanzolini, P. E. 1991b. Two further new species of Amphisbaena from the semi-arid northeast of Brasil (Reptilia, Amphisbaenia). Papéis Avulsos de Zoologia, São Paulo 37: 247-361.

Vanzolini, P. E. 2002. An aid to identification of the South American species of Amphisbaena (Squamata, Amphisbaenidae). Papéis Avulsos de Zoologia, São Paulo 42: 351-362. 